Saudi Journal of Business and Management Studies Abbreviated Key Title: Saudi J Bus Manag Stud ISSN 2415-6663 (Print) |ISSN 2415-6671 (Online) Scholars Middle East Publishers, Dubai, United Arab Emirates Journal homepage: https://saudijournals.com/sibms

Original Research Article

\title{
The Influence of Good Corporate Governance, Earning Per Share, and the Characteristisc of the Company on Earnings Management (Case Study at Banking go public Companies Listed on Indonesia Stock Exchange 2015 - 2018)
}

Fitri Adelina Nasution", Nengzih Nengzih

Mercu Buana University Jakarta

DOI: $10.36348 /$ sjbms.2020.v05i07.005

| Received: 15.06.2020 | Accepted: 04.07.2020 | Published: 11.07.2020

*Corresponding author: Fitri Adelina Nasution

\section{Abstract}

This study aims to examine the effect of the effect of Good Corporate Governance, Earning Per Share, and Company Characteristics on Earnings Management. Good Corporate Governance is measured using indicators of Institutional Ownership, Managerial Ownership, Independent Board of Commissioners, Audit Committee, Earning Per Share, Company Size on Profit ManagementThe banking companies that have gone public are listed on the Indonesia Stock Exchange (IDX) in 2015-2018. The method used is a quantitative method. The population in this study were all banking companies listed on the Indonesia Stock Exchange for four years, namely 2015 - 2018. Determination of the number of samples was carried out using purposive sampling techniques with certain considerations or criteria so that the samples used in this study were 26 companies. Data collection techniques in this study were carried out in several ways, namely by documentation and literature study. The data obtained were then analyzed using the multiple linear regression analysis model using SPSS version 24. However, before multiple regression analysis was performed first, a descriptive statistical regression analysis and a classic assumption test were performed.

Keywords: Institutional Ownership, Managerial Ownership, Independent Board of Commissioners, Audit Committee, Earning Per Share, Company Size and Profit Management.

Copyright @ 2020: This is an open-access article distributed under the terms of the Creative Commons Attribution license which permits unrestricted use, distribution, and reproduction in any medium for non-commercial use (NonCommercial, or CC-BY-NC) provided the original author and source are credited.

\section{INTRODUCTION}

Earnings management is an action that regulates the time of recognition of income, expenses, gains or losses in order to achieve certain desired profit information, without violating the provisions of accounting standards. Usually earnings management is done in the form of increasing profits to achieve certain profit targets and also in the form of lowering profits in this period, in order to increase revenue in the coming period, Dwi Martani [1].

The users of financial statements always focus on the company's profit level because it can show management's achievements in managing the company as well as indicators in measuring management performance. Management's actions to regulate the company's profits as they wish are called earnings management.

\section{The Profit Management Scandal Phenomenon}

Year 2011, Company Orthofix International $\mathrm{NV}$ that recognizes greater income (Overstated) of \$ 1.7 million in 2012. Especially in the third quarter of the 2012 fiscal year which was around \$ 1.4 million. This is due to sales discounts (they refer to as commission for distributors) which are recognized as expenses not as a reduction to income. As well as other cases the Company Maxwell Techonologies, shows Maxwell recognizes revenue of $\$$ 
3.7 million Incorrectly on an Ex Works basis (which means revenue is recognized when goods leave Maxwell's warehouse) for sales to German Distributors on December 22 and December 31, 2011. (US Securities and Exchange Commission).

Year 2012, Maxwell converted losses into profit and recognized an additional \$ 10.3 million in unrecognized revenue from final quarterly contingent sales to German Distributors. This makes the company's revenue growth in the fourth quarter of 2011 to the third quarter of 2012 experience a significant increase (US Securities and Exchange Commission).

Year 2006, PT Kereta Api revealed that there was manipulation of financial statements at PT Kereta Api, where the company should have lost but reportedly benefited, management and public accountants mistakenly audited the placement of value-added tax (VAT) and procurement inventory, resulting in PT KAI's financial position being very different. Hekinus considered that PT KAI should have lost around Rp 600 billion. But the audit results actually recorded PT KAI made a profit of $\mathrm{Rp} \quad 6.9$ billion (www.AntaraNews.com).

The existence of the problems above shows that the financial statements have failed to meet the information needs of the users of the report transparently. Earnings management appears due to agency problems that often occur due to information gaps and also differences in interests between shareholders as principals and company management as agents [2].

In this case, management affects the financial statements for the benefit of management. Influence on financial statements is part of the company's earnings management [3]. Therefore, the implications arising from the existence of a strong GCG in a company are expected to affect the relationship between earnings management and earnings quality [4]. Earnings management arises from agency problems that often occur due to information gaps and also differences in interests between shareholders as the principal and company management as an agent, Rachmawati [5]. To reduce the occurrence of earnings management actions an effective mechanism is needed in managing the company. The mechanism in question is the mechanism of Good Corporate Governance. Good Corporate Governance also aims to create added value for the company's stakeholders and to overcome the problem of agency conflict. Good Corporate Governance using audit committee indicators, board of commissioners, managerial ownership, and institutional ownership, Nengzih [6].

Research on the effect of institutional ownership on earnings management has been conducted by Ratna Mappanyuki, Haryo Dwi Prakoso and Sony
Agus Irwandi [1], Cheng \& Reitenga [7] and Ping \& Koh [8], the greater the institutional ownership the lower the earnings management practices. Institutional ownership is ownership of company shares owned by institutions or institutions (insurance companies, banks, investment companies, governments, and other institutional owners). Some conclude that institutional ownership has a positive effect on earnings management. The results of this study state that institutional ownership influences earnings management, which means that management can monitor effectively and minimize the possibility of earnings management practices occurring.

Good Corporate Governance can be created by increasing managerial ownership in a company. Ebraheem Saleem Salem Alzoubi [9] managerial ownership as an independent variable influences earnings management, because the manager considers that the interests of shareholders are equal to the interests of management so that share ownership can suppress earnings management practices. The results of this study have managerial ownership effect on labba management

Research about independent board of commissioners IGAA Prabaningrat \& AAGP. Widanaputra [10] and Prabaningrat \& Widanaputra [10] conclude that Independent board of commissioners positive effect on earnings management, the higher the level of supervision of the independent commissioner on company performance, the less likely the management to manipulate earnings in the financial statements. The results of this study independent board of commissioners affect earnings management.

Research on the audit committee Lin, and Hwang, has no effect between the audit committee and earnings management and research Ratna Mappanyukki, et al. [1], Normalita [11], Eka [12] have no effect, this can be explained that the appointment of the audit committee by the company may only be carried out to fulfill regulations but is not intended to enforce Good Corporate Governance within the company and the large number of audit committees has not been able to tighten the control system on management. The results of this study did not affect the audit committee earnings management.

Company size as a variable of company characteristics. Research by Aysha Asim and Aisha Ismail [13], and Shen, and Chih [4],Desi Nur Aprina, Khairunnisa [10], Frendy Sutikno [15], Yana Ulfa [16] and Chen et al. [17] positive effect on earnings management means that large companies tend to do smoothing, but good corporate governance can reduce the average effect. The results of this study the size of the company affect earnings management. 
Earning per Share (EPS) or earnings per share is the amount of income earned in a period for outstanding shares. ResearchWellia Novita [18] and Hanafi and Halim [19] there is no effect of earnings per share on earnings management meaning the greater the rate of return on earnings per share (EPS) does not guarantee the amount of earnings management on the financial statements, and conversely the less EPS the lower the level of earnings management on the report. The results of this study earnings per share have no effect on earnings management.

There are fundamental reasons why managers do earnings management. The stock market price of a company is significantly influenced by earnings, risk, and speculation. Therefore, companies whose profits always increase from period to period consistently will result in a risk of this company experiencing a greater decline compared to the percentage of profit affected. This has resulted in many companies that manage and manage earnings as an effort to reduce risk.

Based on the above background, the writer would like to take a research discussion with the title "The Effect of Good Corporate Governance, Earning Per Share, and Company Characteristics on Earnings Management" (Case Study on Banking Companies that have been publicly listed on the Indonesia Stock Exchange (BEI) year 2015-2018).

\section{LITERATURE REVIEW Agency Theory}

Agency theory is rooted in economic theory presented by Alchian and Demsetz, and subsequently developed by Jensen and Meckling [20]. This theory focuses on the separation of ownership and control of the company Bhimani [21] highlighting the relationship between principals (shareholders), agents (eg company executives) and managers.Agency Theory explain the relationship between the agent (the management of a company) and the principal (owner). Principal is the party that gives the mandate to the agent to perform a service on behalf of the principal, while the agent is the party that is mandated. Thus the agent acts as the party that has the authority to make decisions, while the principal is the party that evaluates information

\section{Good Corporate Governance and Profit Management Mechanisms}

Corporate Governance is a set of rules and control tools that will lead to the achievement of objectives, clarity, fairness, and analysis of the rights of stakeholders to manage activities, policies, arrangements, processes, traditions and systems. The quality of peak income reporting has led to a company's financial status through annual performance reports during defining the fiscal year in an appropriate and sincere approach. If the manager's goals are fully in line with shareholders' benefits or conflicts of interest are not among them, there is no need for managers to describe imaginary statements of the company's position to shareholders. Corporate governance has the ability to reduce agency costs and it leads to promoting quality in reported earnings because it gets high value in the market. According to Karmanaou, I. and N. Vafeas [22] that companies that have effective governance are more likely to make or update management estimates.

To reduce the occurrence of earnings management actions an effective mechanism is needed in the management of the company. The mechanism in question is the mechanism of Good Corporate Governance. The corporate governance mechanism as measured by the audit committee, the board of commissioners, managerial ownership, and institutional ownership, Nengzih [6]. These mechanisms include institutional ownership, managerial ownership by the company, the existence of an independent board of commissioners and an audit committee is the implementation of GCG implementation. Siti Aisyah and Hari Setiyawati [13], the position of the independent board of commissioners functions as a supervisor and provides advice to the board of directors. To assist the commissioners' duties in the company the weight control function is assisted by an audit committee.

Therefore, this study predicts good corporate governance in banking companies has a positive effect on earnings management, as hypothesized below:

$\mathrm{H}_{1}=$ Institutional ownership has a significant effect on earnings management

$\mathrm{H}_{2}=$ Managerial Ownership has a significant effect on earnings management

$\mathrm{H}_{3}=$ Independent Board of Commissioners has significant effect on earnings management

$\mathrm{H}_{4}=$ The Audit Committee has a significant effect on earnings management

\section{Earning Per Sare and Profit Management}

Earnings per Share or income per share is a form of giving benefits to shareholders from each share owned. As according to Van Horne and Wachowicz, Earning per Share is "Earning after taxes (EAT) devided by the number of common shares outstanding" [23].

Kasmir [24] also believes that the earnings per share ratio (also known as book value ratio) is a ratio to measure the success of management in achieving profits for shareholders. A low ratio means that management has not succeeded in satisfying shareholders, on the contrary with a high ratio, the welfare of shareholders increases with another understanding, that the rate of return is high.

From the description above earnings per share can influence managers to practice earnings management by measuring the net income of each 
company by the number of shares outstanding. Therefore, this study predicts earnings per share in banking companies to have a positive effect on earnings management, as hypothesized below:

$\mathrm{H}_{5}=$ Earning Per Sahre has a significant effect on earnings management

\section{Company Size and Profit Management}

The size of the company is a value that indicates the size of the company. The size of a small company is considered to do more earnings management than large companies. This is because the larger the size of the company, usually the information available to investors in making decisions regarding investment in the company's shares more and more large companies more attention by the public so they are more careful in reporting financial statements, so that the impact of the company reported the conditions are more accurate[25].

Effect of Company Size on Profit Management. The size of the company describes the size of a company that is indicated by the company's total assets. The greater the total assets of the company, the greater the size of the company. Large companies tend to have an incentive to manage earnings compared to small companies, because large companies are seen as more critical by outsiders such as investors, creditors, and the government.

Therefore, this study predicts earnings per share in banking companies to have a positive effect on earnings management, as hypothesized below:

$\mathrm{H}_{6}=$ Company size has a significant effect on earnings management

\section{Frame Work}

Based on the literature review above, the framework can be described as follows:

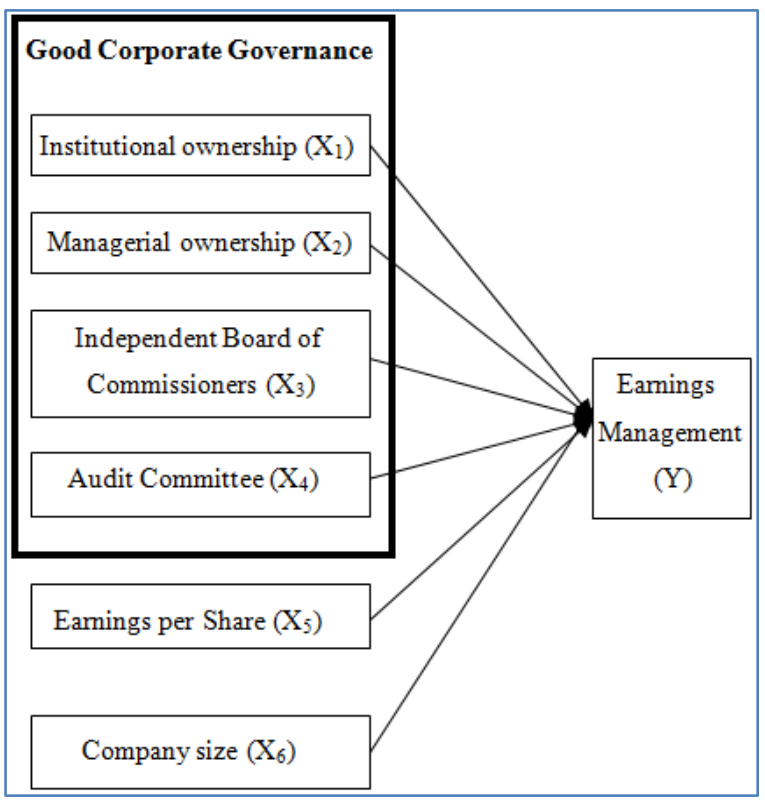

\section{HYPOTHESIS}

A number of previous studies have shown Research on the effect of institutional ownership on earnings management conducted by Ratna Mappanyuki, Haryo Dwi Prakoso and Sony Agus Irwandi [1], and Ismailia Asward and Lina [10] concluded that institutional ownership has a positive effect on earnings management. Institutional ownership can effectively monitor management and can minimize the possibility of earnings management practices occurring, so the researcher proposes the following hypothesis:

\section{$H_{1}$ : Institutional ownership positive effect towards earnings management.}

Research on the effect of managerial ownership on earnings management has been conducted Luh Made Dwi Parama Yogi and I Gusti Ayu Eka Damayanthi [12], and Suci Anggan and Muhammad Rafki Nazar [2] concluded that managerial ownership has a positive effect on earnings management. Managerial ownership can be stated that the owner with a large number of shares can carry out the oversight function more optimally, so the researcher proposes the following hypothesis:

\section{$\mathrm{H}_{2}$ : Managerial ownership positive effect towards earnings management.}

The Independent board of commissioners IGAA Prabaningrat \& AAGP. Widanaputra [10] and Prabaningrat \& Widanaputra [10] conclude that Independent board of commissioner's positive effect on earnings management, the higher the level of supervision of independent commissioners on company performance, the less likely the management to manipulate earnings in financial statements, so the researcher proposes the following hypothesis:

\section{$\mathrm{H}_{3}$ : Independent board of commissioner's positive effect towards earnings management}

The audit committee negatively influences earnings management practice, Dimas Adriansyah Putra, Farida Titik Kristanti and Wiwin Aminah [26] and Vajriyanti, et al. [19] which stated that the existence of the audit committee did not significantly influence earnings management because the company only formed audit membership for just fulfill the regulations and not someone who is an expert in their field so that they are not professional at work, so the researcher proposes the following hypothesis:

\section{$H_{4}$ : The audit committee has a positive effect on earnings management}

Fricilia and Hendro [17] as well Sumawiyah, Budi Wahono and Ronny Malavia Mardani [28] concluded concluded Earning per share has an effect on earnings management, is stated that the company was able to make profits based on shares owned, if the company had outstanding options or warranties, the company had a complex capital structure, 
$\mathrm{H}_{5}$ : Earning Per Share positive effect towards earnings management

Research on company size conducted by Clarissa Taco and Ventje Ilat [19], and Erik Indracahya \& Dewi A. Faisol [12] can be concluded that the larger the size of the company, the lower the possibility of earnings management, so the researcher proposes the following hypothesis:

\section{$H_{6}$ : Company size positive effect towards earnings management}

\section{RESEARCH METHODS}

This type of research is quantitative descriptive research. The purpose of this descriptive study is to provide a descriptive, systematic, factual and accurate description of the facts, properties and relationships between the phenomena investigated. Data will be used in this study 26 samples were used as research by using purposive sampling technique. Data collection techniques used in this study is archival data collection techniques, namely data collection methods sourced from the Indonesia Stock Exchange (IDX) website, namely www.idx.co.id. The research period is conducted from 2015 - 2018. This study uses the SPSS 24 for Windows program for data processing.

\section{RESULTS AND DISCUSSION Object of Research}

The object of this research is a publicly listed banking company listed on the Indonesia Stock Exchange (IDX) in Jakarta period 2015 - 2018, as many as 43 companies. Based on sample selection using purposive techniques sampling so the companies sampled in this study were 26 companies. Years of observation each company for 4 years (2015 - 2018), so that the number of observations obtained was 104 observational data.

\section{Descriptive Analysis}

Descriptive statistics work to describe or provide a description of the object that is done through sample data received without analyzing or making generally accepted conclusions. So the descriptive analysis reacts to the research variables but their own nature, disagrees with the others [29]. Average, maximum, minimum, and standard deviation [30].

Table-1

\begin{tabular}{|l|r|r|r|r|r|}
\hline \multicolumn{7}{|c|}{ Descriptive Statistics $^{1}$} \\
\hline & \multicolumn{1}{c|}{$\mathrm{N}$} & \multicolumn{1}{c|}{ Min } & \multicolumn{1}{c|}{ Max } & \multicolumn{1}{c|}{ Mean } & Std. Deviation \\
\hline X(KI)' & 104 & 1,827 & 376,848 & 57,56263 & 74,889403 \\
\hline X2(KM)' & 104 &, 0004 & 6,3700 &, 862277 & 1,2052409 \\
\hline X3(DKI)' & 104 & 28,33 & 100,00 & 56,7247 & 12,22923 \\
\hline X4(KA)' & 104 & 3,00 & 6,00 & 3,6154 &, 77969 \\
\hline X5(EPS)' & 104 & $-43,53$ & 73,08 & 7,2315 & 16,32943 \\
\hline X6(UP)' & 104 & 7,81 & 24,13 & 16,5899 & 3,43147 \\
\hline MNJM_LABA & 104 &,- 07560 &, 12090 &,- 0005106 &, 03064838 \\
\hline Valid N (listwise) & 104 & & & & \\
\hline
\end{tabular}

Source : Results of data processing with SPSS (2019)

\section{Based on the descriptive statistic test, the following} results are

1. $\mathrm{N}=104$ means the amount of data processed in this study is 104 samples consisting of 26 companies used for 4 years consisting of Institutional Ownership, Managerial Ownership, Independent Board of Commissioners, Company Size, Earning Per Share and Earnings Management.

2. For the Institutional Ownership variable the number of data is 104, the minimum Institutional Ownership is 23.63 while the maximum is 99.27 . With a mean value of 65.5116 and a standard deviation of 22.74381 , indicating a mean value greater than the standard deviation can be said to say that the deviation of data on institutional ownership is relatively good.

3. For the Managerial Ownership variable the amount of data is 104, then Minimum Managerial Ownership is 0.0004 while the maximum is equal to 6.3700, mean 0.862277 and std. deviation 1.20524. The standard deviation value is greater than the mean (mean) indicating that only a portion of the companies whose ownership is dominated by managerial

4. For the Independent Board of Commissioners variable the amount of data is 104 , has the minimum percentage value is $28.33 \%$ and the maximum value is $100 \%$. The mean value is $56.724 \%$ and the standard deviation is $12.222 \%$. An average value that is greater than the standard deviation indicates that the position of the independent commissioner in a banking company is good.

5. For the Audit Committee variable the amount of data is 104, has a minimum value of 3.00 and a maximum value of 6.00 . The mean value is 3.61 and the standard deviation is 0.779 . The standard deviation value is greater than the mean (mean) indicating the position of the audit committee in the banking company is said to be good.

6. For Earning Per Share variable the amount of data is 104, has a value minimum of -43.53 , maximum value of 73.08. The mean value is 16.5899 and the standard deviation is 3.43147 . Seeing the standard deviation is greater than the mean (mean) means that 
the company's ability to achieve Earning Per Share (EPS) in this study has a high enough level of variation or there is a large gap from the lowest and highest EPS percentage.For company size variables, the amount of data is 104 , has a value minimum of 7.81. The maximum value is 24.13 . The mean value is 16.5899 and the standard deviation is 3.43147 . This shows that the size of the company in this study ranged from 7.81 to 24.13 with an average size of the company amounting to 18.9553 or around 600 million rupiah. This shows that the companies sampled in this study were dominated by mediumsized companies.

\section{Classic assumption test}

Test assumptions classically consist of four kinds: namely normality, multicollinearity, heteroscedasticity, and autocorrelation, which are in explain as follows:

\section{(i) Normality test}

The results of normality testing in this study can be seen as follows:

Table-2: One-Sample Kolmogorov-Smirnov Test

\begin{tabular}{|c|c|c|}
\hline & & $\begin{array}{c}\text { Unstandardize } \\
\text { d Residual }\end{array}$ \\
\hline \multicolumn{2}{|l|}{$\mathrm{N}$} & 104 \\
\hline \multirow[t]{2}{*}{ Normal Parameters ${ }^{\mathrm{a}, \mathrm{b}}$} & Mean & ,0000000 \\
\hline & Std. Deviation & ,02716918 \\
\hline \multirow{3}{*}{$\begin{array}{l}\text { Most Extreme } \\
\text { Differences }\end{array}$} & Absolute & ,086 \\
\hline & Positive & ,086 \\
\hline & Negative &,- 065 \\
\hline \multicolumn{2}{|l|}{ Test Statistic } & ,086 \\
\hline \multicolumn{2}{|l|}{ Asymp. Sig. (2-tailed) } &, $058^{\mathrm{c}}$ \\
\hline \multicolumn{3}{|c|}{ a. Test distribution is Normal. } \\
\hline \multicolumn{3}{|l|}{ b. Calculated from data. } \\
\hline \multicolumn{3}{|c|}{ c. Lilliefors Significance Correction. } \\
\hline
\end{tabular}

The basis for decision making is if 2-tailed > 0.05 , then the regression model meets the normality assumption. The value of Kolmogorov-Smirnov $\mathrm{Z}$ is 0.086 and significant at 0.058 . The size of asymp sig 2tailed $\geq 5 \%$, this means that $\mathrm{H}_{0}$ is received, which means that the residual data is normally distributed.

\section{(ii) Multicollinearity Test}

The results of multicollinieriatas in this study can be seen as follows:

Table 3

\begin{tabular}{|c|c|c|c|c|c|c|c|c|}
\hline \multicolumn{9}{|c|}{ Coefficients $^{\text {a }}$} \\
\hline \multirow{2}{*}{\multicolumn{2}{|c|}{ Model }} & \multicolumn{2}{|c|}{$\begin{array}{c}\text { Unstandardized } \\
\text { Coefficients }\end{array}$} & \multirow{2}{*}{\begin{tabular}{|c|}
$\begin{array}{c}\text { Standardized } \\
\text { Coefficients }\end{array}$ \\
Beta \\
\end{tabular}} & \multirow[t]{2}{*}{$\mathbf{t}$} & \multirow[t]{2}{*}{ Sig. } & \multicolumn{2}{|c|}{ Collinearity Statistics } \\
\hline & & B & $\begin{array}{l}\text { Std. } \\
\text { Error }\end{array}$ & & & & Tolerance & VIF \\
\hline \multirow[t]{7}{*}{1} & (Constant) &,- 012 &, 025 & &,- 475 & ,636 & & \\
\hline & $\mathrm{X}(\mathrm{KI})^{\prime}$ &, 000 &, 000 & ,349 & 3,703 & ,000 & ,914 & 1,094 \\
\hline & $\mathrm{X} 2(\mathrm{KM})^{\prime}$ &, 005 & ,002 &, 193 & 2,062 &, 042 & ,924 & 1,082 \\
\hline & $\mathrm{X} 3(\mathrm{DKI})^{\prime}$ &, 001 & ,000 & 227 & 2,493 &, 014 & ,981 & 1,019 \\
\hline & $\mathrm{X} 4(\mathrm{KA})^{\prime}$ &, 000 & ,004 &,- 010 &,- 104 & ,917 & ,922 & 1,084 \\
\hline & X5(EPS)' &, 000 & , 000 &,- 079 &,- 873 & ,385 & ,980 & 1,020 \\
\hline & $\mathrm{X6(UP)^{ \prime }}$ &,- 002 & ,001 &,- 207 & $-2,148$ &, 034 & ,871 & 1,148 \\
\hline
\end{tabular}

This table shows that between independent variables multicollinearity does not occur. This can be seen from the results of testing none of the independent variables that have a tolerance value of less than 0.10 means there is no correlation between the independent variables whose value is more than $95 \%$ [31]. VIF value calculation results also show the same thing that there is no single variable that has a VIF value of more than 10 .
So it can be said that there is no multicollinearity between the independent variables in the regression model.

\section{(iii) Heteroskedesticity Test}

It can be concluded that the regression model is free from heteroscedasticity symptoms: 
Table-4

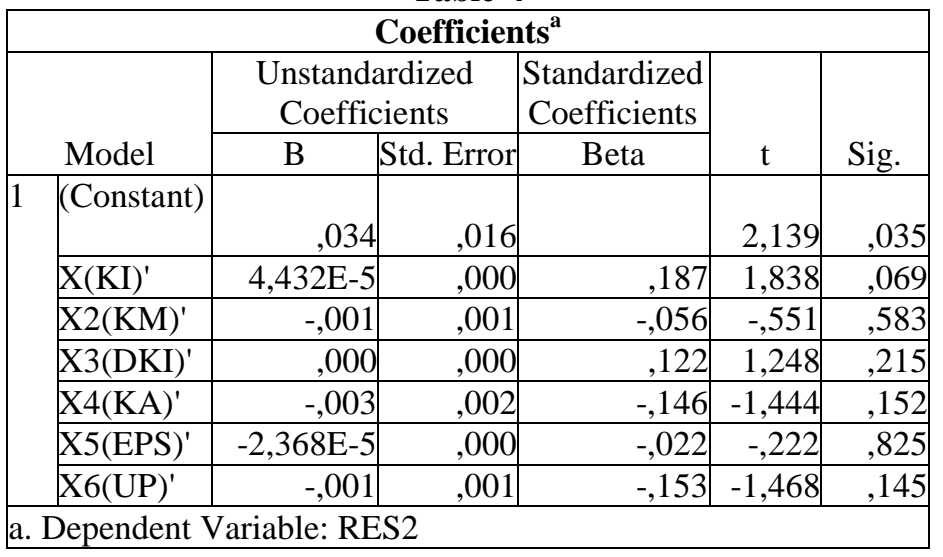

From this table shows the regression model used in this study does not occur heteroscedasticity, where it can be seen the level of significance for all independent variables above 0.05 or $5 \%$. If the independent variable significantly influences the dependent variable which is indicated by a significance of less than 5\%, then the regression model occurs heteroscedasticity.

\section{(iv) Autocorrelation Test}

Table-5

\begin{tabular}{|c|c|c|c|c|}
\hline \multicolumn{5}{|c|}{ Model Summary $^{b}$} \\
\hline Model & $\mathrm{R}$ & R Square & \begin{tabular}{c|c|}
$\begin{array}{c}\text { Adjusted R } \\
\text { Square }\end{array}$ & $\begin{array}{c}\text { Std. Error of } \\
\text { the Estimate }\end{array}$ \\
\end{tabular} & $\begin{array}{l}\text { Durbin- } \\
\text { Watson }\end{array}$ \\
\hline 1 &, $463^{\mathrm{a}}$ & 214 & ,02800 & 2,311 \\
\hline \multicolumn{5}{|c|}{$\begin{array}{l}\text { a. Predictors: (Constant), X6(UP)', X3(DKI)', X5(EPS)', X2(KM)', } \\
\text { X4(KA)', X(KI)' }\end{array}$} \\
\hline
\end{tabular}

The Durbin Watson (DW) value of regression at the significant level (a) $0.05, \mathrm{k}=7, \mathrm{n}=104$ is 2.311 . While the size of the DW table is: $\mathrm{dl}=1.5399, \mathrm{du}=$ $1.8261,4-\mathrm{dl}=2.4601$ and $4-\mathrm{du}=2.1739$. Then, the results of Dw $(2,311)>d u(1,8261)$ results, so it can be concluded that this multiple linear regression model is free from autocorrelation.

Model Conformity Test

(i) Coefficient of Determination $\left(\mathbf{R}^{2}\right)$

Table-6

\begin{tabular}{|l|c|c|c|c|}
\hline \multicolumn{5}{|c|}{ Model Summary } \\
\hline Model & $\mathrm{R}$ & $\begin{array}{c}\mathrm{R} \\
\text { Square }\end{array}$ & $\begin{array}{c}\text { Adjusted } \\
\text { R Square }\end{array}$ & $\begin{array}{c}\text { Std. Error of the } \\
\text { Estimate }\end{array}$ \\
\hline 1 &, $463^{\mathrm{a}}$ &, 214 &, 166 &, 02800 \\
\hline \multicolumn{3}{|c|}{ a. Predictors: (Constant), X6(UP)', X3(DKI)', X5(EPS)', } \\
X2(KM)', X4(KA)', X(KI)' \\
\hline
\end{tabular}

From the table 6 shows the value of adjusted R2 0.166 which means that $16,6 \%$ of the Earnings Management variable can be explained by the variables of Institutional Ownership, Managerial Ownership, Independent Board of Commissioners, Audit Committee, Earning Per Share, and Size Company while the remaining $83,4 \%$ is explained by other variables outside regression model.

\section{Model Feasibility Test (Test F)}

The $\mathrm{F}$ test is used to support the feasibility of the regression model that has been formed. Testing is done by comparing the value of $\mathrm{F}$ table with $\mathrm{F}$ count. The test criteria are the probability value ( $\mathrm{Sig}$ ) is smaller than $5 \%$, then the independent variable depends on the dependent variable. In this study, the study reached a $\mathrm{F}$ probability level of 0.05 . Related, the eligibility criteria of the model in this study must be $\leq 0.05$, Ghozali [31]. 


\begin{tabular}{|c|c|c|c|c|c|}
\hline \multicolumn{6}{|c|}{ ANOVA $^{\mathrm{a}}$} \\
\hline Model & $\begin{array}{l}\text { Sum of } \\
\text { Squares }\end{array}$ & df & $\begin{array}{l}\text { Mean } \\
\text { Square }\end{array}$ & $\mathrm{F}$ & Sig. \\
\hline \begin{tabular}{|l|l}
1 & Regression \\
\end{tabular} &, 021 & 6 & 003 & 4,406 &, $001^{1}$ \\
\hline Residual & 076 & 97 &, 001 & & \\
\hline Total & 097 & 103 & & & \\
\hline \multicolumn{6}{|c|}{ a. Dependent Variable: MNJM_LABA } \\
\hline \multicolumn{6}{|c|}{$\begin{array}{l}\text { b. Predictors: (Constant), X6(UP)', X3(DKI)', X5(EPS)', } \\
\text { X2(KM)', X4(KA)', X(KI)' }\end{array}$} \\
\hline
\end{tabular}

Based on the hypothesis test results table above, the Fvalue is to 4.406 and Ftable of 2.19 means Fvalue than Ftable $(4.406>2.19)$. From the results of testing the hypothesis and comparison between Fhitung with Ftable, it can be concluded H0 This means that Institutional Ownership, Managerial Ownership, Independent Board of Commissioners, Audit
Committee, Company Size, and Earning Per Share together have an influence on earnings management.

\section{Hypothesis testing \\ Partial Significant Test (T-test)}

T-test aims to determine the magnitude of each effect each independently of the dependent.

Table-8

\begin{tabular}{|c|c|c|c|c|c|c|}
\hline \multicolumn{7}{|c|}{ Coefficients $^{\mathrm{a}}$} \\
\hline \multirow{2}{*}{\multicolumn{2}{|c|}{ Model }} & \multicolumn{2}{|c|}{$\begin{array}{l}\text { Unstandardized } \\
\text { Coefficients }\end{array}$} & \multirow{2}{*}{\begin{tabular}{|c|}
$\begin{array}{c}\text { Standardized } \\
\text { Coefficients }\end{array}$ \\
Beta \\
\end{tabular}} & \multirow[b]{2}{*}{$\mathrm{t}$} & \multirow[b]{2}{*}{ Sig. } \\
\hline & & $\mathrm{B}$ & Std. Error & & & \\
\hline 1 & (Constant) &,- 012 &, 025 & &,- 476 & ,635 \\
\hline & $\mathrm{XI}(\mathrm{KI})^{\prime}$ & ,000 &, 000 & ,340 & 3,597 & ,001 \\
\hline & $\mathrm{X} 2(\mathrm{KM})^{\prime}$ & ,005 & ,002 & ,191 & 2,038 & ,044 \\
\hline & $\mathrm{X} 3(\mathrm{DKI})^{\prime}$ & ,001 & ,000 & ,228 & 2,496 & ,014 \\
\hline & $\mathrm{X} 4(\mathrm{KA})^{\prime}$ & ,000 & ,004 &,- 010 &,- 106 & ,916 \\
\hline & X5 (EPS)' & ,000 & ,000 &,- 080 &,- 872 & ,385 \\
\hline & X6(UP)' &,- 002 & ,001 &,- 206 & $-2,127$ & ,036 \\
\hline
\end{tabular}

Based on the results of the table 8 above, the following hypothesis testing T-test can be made:

\section{Hypothesis 1}

The first hypothesis is Institutional Ownership Variable has a $t$ value of 3.597 and sig. of 0.001 or smaller than 0.05 , this shows that the variable Institutional Ownership has a significant effect on Earnings Management.

\section{Hypothesis 2}

The second hypothesis is Managerial Ownership Variable has a t value of 2.038 and sig. of 0.044 or smaller than 0.05 , this shows that the Managerial Ownership variable has a significant effect on Earnings Management.

\section{Hypothesis 3}

The third hypothesis is Independent Board of Commissioners variable has a $\mathrm{t}$ value of 2 . and sig. of 0.014 or greater than 0.05 , this shows that the
Independent Board of Commissioners variable has a significant effect on Earnings Management.

\section{Hypothesis 4}

The fourth hypothesis is Audit Committee variable has a $t$ value of -0.106 and sig. of 0.916 or greater than 0.05, this shows that the Audit Committee variable does not have a significant effect on Earnings Management.

\section{Hypothesis 5}

The six hypothesis is Earning Per Share variable has a t value of -0.872 and a sig value. of 0.385 or greater than 0.05, this shows that the Earning Per Share variable does not have a significant effect on Earnings Management.

\section{Hypothesis 6}

The fifth hypothesis is company size variable has a $t$ value of -2.127 and sig. of 0.036 or smaller than 0.05 , this shows that the Company Size variable has a significant effect on Earnings Management. 
(ii) Multiple Regression Analysis

Table-9

\begin{tabular}{|c|c|c|c|c|c|c|}
\hline \multicolumn{7}{|c|}{ Coefficients $^{\mathrm{a}}$} \\
\hline \multirow{2}{*}{\multicolumn{2}{|c|}{ Model }} & \multicolumn{2}{|c|}{$\begin{array}{l}\text { Unstandardized } \\
\text { Coefficients }\end{array}$} & \multirow{2}{*}{$\begin{array}{c}\begin{array}{c}\text { Standardized } \\
\text { Coefficients }\end{array} \\
\text { Beta }\end{array}$} & \multirow[t]{2}{*}{$\mathbf{t}$} & \multirow[t]{2}{*}{ Sig. } \\
\hline & & $\mathrm{B}$ & Std. Error & & & \\
\hline \multirow[t]{7}{*}{1} & (Constant) &,- 012 & ,025 & &,- 476 & 635 \\
\hline & $\mathrm{XI}(\mathrm{KI})^{\prime}$ & ,000 & ,000 & ,340 & 3,597 & ,001 \\
\hline & $\mathrm{X} 2(\mathrm{KM})^{\prime}$ &, 005 &, 002 & 191 & 2,038 & ,044 \\
\hline & X3(DKI)' & 001 &, 000 & 228 & 2,496 & ,014 \\
\hline & $\mathrm{X} 4$ (KA)' &, 000 & ,004 &,- 010 &,- 106 & ,916 \\
\hline & X5 (EPS)' & 000 &, 000 &,- 080 &,- 872 &, 385 \\
\hline & X6(UP)' &,- 002 & ,001 &,- 206 & $-2,127$ & ,036 \\
\hline
\end{tabular}

Based on the results of these calculations, the regression equation can be formulated as follows:

\section{$\mathrm{Y}=-0.012+(0.000) \mathrm{X} 1+0.005 \mathrm{X} 2+0.001 \mathrm{X} 3+$ $0.000 \times 4+0.000 \times 5+-0.002 \times 6+e$}

Then the results of this regression test are also meaningful as follows:

a. A constant of $-0,012$ states that if the value of earnings management is total institutional ownership, managerial ownership, independent board of commissioners, audit committee, earnings per share and company size, Profitability value is 0 , then Profit Management value is $-0,012$.

b. Regression coefficient X1 of 0,000 , this means that every change in 1 unit the level of institutional ownership can add or decrease Earnings Management by 0,000 .

c. Regression coefficient X2of 0.005 , this means that every change in 1 unit managerial ownership level, it can add Management Profit of 0.005

d. Regression coefficient of X3 0.001 this means that every change in 1 unit the level of the independent board of commissioners, it can add a Profit Management of .001.

e. Regression coefficient $\mathrm{X} 4$ of 0,000 this means that every change in 1 unit audit committee level, it can add or decrease Earnings Management by 0,000 .

f. Regression coefficient X5 of 0,000, this means that every change in 1 unit the level of earnings per share, it can increase or decrease Profit Management by 0,000 .

g. Regression coefficient X6 of -0.002 , this means that every change 1 the unit size of the company, then can reduce Profit Management by 0.002 .

\section{DISCUSSION}

\section{i. The first hypothesis (Effect of Managerial Ownership on Earnings Management)}

Regression coefficient for Institutional Ownership, by analyzing Institutional Ownership of 0.001 under the significance of $0.05(0.001<0.05)$, which means that institutional ownership has a significant effect on earnings management. Institutional ownership has influence with earnings management. Research conducted by Nengzih, Nengzih [6] and Ratna Mappanyuki, Haryo Dwi Prakoso and Sony Agus Irwandi [1] Institutional ownership affect earnings management. Large institutional ownership is a way to oversee managers. Increasing institutional ownership can reduce agency cost on debt and insider ownership because the greater institutional ownership can reduce the occurrence of conflicts between creditors and managers, and ultimately can reduce agency costs. The first hypothesis "H1: Institutional ownership has a significant effect on earnings management", was accepted.

\section{ii. The second hypothesis (Effect of Managerial Ownership on Earnings Management)}

Managerial Ownership Results 0.044 under the significance of $0.05(0.044<0.05)$, which means that managerial ownership has a significant influence on earnings management. Managerial ownership has a positive relationship with earnings management. These results are in line with the research of Suci Anggani, Muhammad Rafki Nazar [2] and Eva Rosa Dewi S, Moh. Khoiruddin [32] this indicates that managerial ownership can be mechanism corporate governance which can reduce the misalignment of interests between management and owners and shareholders. The second hypothesis "H2: Managerial ownership has a significant influence on earnings management", is accepted.

\section{iii. The third hypothesis (The influence of the Independent Commissioners on Profit Management) \\ Researching independent commissioners of} 0.014 , under the significance of $0.05(0.014<0.05)$, means that the board of independent commissioners has a significant influence on earnings management. The independent board of commissioners has a significant effect on earnings management, this result is in line with research by Hikmah Is'ada Rahmawati [16], stating that the greater number of members of the board of commissioners will give small results on the possibility of earnings management. The third hypothesis "H3: 
Board of Commissioners Independent has a significant influence on earnings management ", accepted.

\section{iv. The fourth hypothesis (The influence of the Audit Committee on Profit Management)}

Audit Committee Results 0.916 significance above $0.05(0.16>0.05)$, meaning that the audit committee has no significant effect on earnings management, this result is in line with this study in line with research results from Yayan Nuryana and Dwi Asih Surjandari [33], Normalita [34], Eka [12] appointment of audit committees by companies may only be done to fulfill regulations but it is not intended to enforce Good Corporate Governance within the company and the large number of audit committees have not been able to tighten up management system. Hypothesis fourth "H4: Audit Committee has no significant effect on earnings management", was rejected.

\section{v. The sixth hypothesis (Effect of Earning Per Share on Earnings Management)}

After regression and testing, Earning Per Share (EPS) 0.385 , above the significance of 0.05 (0.385 > 0.05), meaning that Earning Per Share does not have a significant effect on earnings management. This result is in line with Wellia Novita [18] and Hanafi and Halim [35]. There is no effect of earnings per share on earnings management, meaning that the greater the rate of return on earnings per share (EPS) does not guarantee the amount of earnings management on the financial statements, and vice versa. EPS then decreases the level of earnings management on the report. The sixth hypothesis "H6: Earning per Share has no significant effect on earnings management", was rejected.

\section{vi. The fifth hypothesis (Effect of Company Size on Profit Management)}

After regression and testing, the Company Size is 0.023 , under the significance of $0.05(0.036<0.05)$, meaning that the size of the company has a significant influence on earnings management. This result is in line with Syed Zulfikar Ali Shah, Safdar Ali Butt, Arshad Hasan [36] and Aprih Santoso, Diana Puspitasari and Rahmatya Widyaswati [38] which shows that large companies that go public tend to be closely watched by capital markets and investors so management tends to report financial performance transparently. The fifth hypothesis "H5: Firm size has a significant influence on earnings management", was accepted.

\section{CONCLUSION}

Based on the results of research conducted and through several hypothesis tests, the following conclusions are obtained:

1. Institutional ownership has a significant effect on earnings management. Institutional ownership increases, earnings management will also increase. The reason is, the company is able to finance its operational activities with its own capital, so there is no need to attract outside parties to invest.

2. Managerial ownership has a significant effect on earnings management. An increase in managerial ownership will align interests between shareholders and managers, so that managers can engineer profits in reducing agency cost.

3. Independent commissioners have a significant effect on earnings management. Thing this shows that the addition or presence of an independent commissioner increases the effectiveness in overseeing management to prevent the occurrence of earnings management practices.

4. The audit committee has no significant effect on earnings management. This matter showing independence and the number of members is not the most important thing that must be owned by the audit committee.

5. Earnings Per Share has no significant effect on earnings management concluded that earning per share in banking companies that tend to have small earnings per sheet will result in low profits and encourage companies to manage earnings and the greater earning per share, the more indicated the company is doing earnings management.

6. The size of the company has a significant effect on meaningful earnings management Earnings management occurs in large companies because these companies tend to avoid earnings losses.

\section{REFERENCE}

1. Mappanyukki, R., Prakoso, H. D., \& Irwandi, S. A. (2016). The Impact of Free Cash Flow and Good Corporate Governance on Earning Management of Banking Companie Listed on The Indonesian Stock Exhange. Research Journal of Finance and Accounting, 7.

2. Suci, A., Muhammad, R.N. (2013). The Effect of Managerial Ownership, Institutional Ownership, and Leverage on Profit Management Practices. EProceeding of Management, 2(3).

3. Hassan, S. U., \& Ahmed, A. (2012). Corporate governance, earnings management and financial performance: A case of Nigerian manufacturing firms. American International Journal of Contemporary Research, 2(7), 214-226.

4. Rice. (2013). The Effects of Leverage, Institutional Ownership, Size and Firm Value on Earnings Management Actions. Journal of Microeconomic Entrepreneur, 3(1).

5. Rahmawati, Wisdom Is' There. (2013). The Effect of Good Corporate Governance (GCG) on Profit Management in Banking Companies. Accounting Analysis Journal AAJ, 2(1)

6. Nengzih. (2017). Determinant of Corporate Governance, Audit Quality and Financing Decision. Research Journal of Finance and Accounting, 8(8)

7. García- Meca, E., \& Sánchez- Ballesta, J. P. (2009). Corporate governance and earnings 
management: A meta- analysis. Corporate governance: an international review, 17(5), 594610.

8. Rachmawati, H., Edityaningrum, C. A., \& Mauludin, R. (2013). Molecular inclusion complex of curcumin- $\beta$-cyclodextrin nanoparticle to enhance curcumin skin permeability from hydrophilic matrix gel. Aaps Pharmscitech, 14(4), 1303-1312.

9. Alzoubi, E. S. S. (2016). Audit quality and earnings management: evidence from Jordan. Journal of Applied Accounting Research.

10. Vajriyanti, E., Widanaputra, A. A. G. P., \& Putri, I. G. A. M. (2015). Pengaruh Manajemen Laba Riil pada Nilai Perusahaan dengan Good Corporate Governance sebagai Variabel Pemoderasi. Simposium Nasional Akuntansi XVIII, USU Medan.

11. Dzingai, I., \& Fakoya, M. B. (2017). Effect of corporate governance structure on the financial performance of Johannesburg Stock Exchange (JSE)-listed mining firms. Sustainability, 9(6), 867.

12. Indracahya, E., \& Faisol, D. A. (2017). The Effect of Good Corporate Governance Elements, Leverage, Firm Age, Company Size and Profitability on Earning Management (Empirical Study of Manufacturing Companies in Bei 20142016). Profita, 10(2), 203-227.

13. Aisyah, S., \& Setiyawati, H. (2019). The Effect of Executive Character and Implementation of Good Corporate Governance to Tax Avoidance (Empirical Study on Companies Moving Consumer Goods Sector Industry Listed in Indonesian Stock Exchange in 2013-2017).

14. Shen, C. H., \& Chih, H. L. (2007). Earnings management and corporate governance in Asia's emerging markets. Corporate Governance: An International Review, 15(5), 999-1021.

15. Sutikno, F. (2014). Pengaruh Corporate Governance Dan Ukuran Perusahaan Terhadap Manajemen Laba Di Industri Perbankan Indonesia. Jurnal ilmu \& riset akuntansi, 3(10).

16. Wahyudin, A., \& Solikhah, B. (2017). Corporate governance implementation rating in Indonesia and its effects on financial performance. Corporate Governance: The International Journal of Business in Society.

17. Chen, L. J., \& Chen, S. Y. (2011). The influence of profitability on firm value with capital structure as the mediator and firm size and industry as moderators. Investment Management and Financial Innovations, 8(3), 121-129.

18. Wellia, N. (2017). Effect of Total Assets, Debt Equity Ratio and Earning Per Share on Profit Management at PT Adhi Karya (Persero) Tbk, Putra Indonesia University (UPI) "YPTK" Padang RAK, 8(2), 1-12

19. Taco, C., \& Ilat, V. (2016). Effects of Earning Power, Independent Commissioners, Board of Directors, Audit Committee, and Company Size on
Profit Management. EMBA Journal of Sam Ratulangi University Manado. Vol.4, No.2, 873884

20. Jensen, M. (1976). Meckling. 1976. Theory of the Firm: Managerial Behaviour, Agency Costs, and Ownership Structure, 22.

21. Bhimani, A., \& Horngren, C. T. (2008). Management and cost accounting (Vol. 1). Pearson Education.

22. Younis, S. A., Hashmi, S. H., Khalid, G. K., \& Nazir, M. I. (2016). Impact of corporate governance measures on earnings quality: evidence from Pakistan. Research Journal of Finance and Accounting, 7(3), 9-16.

23. Fahmi, I. Hadi. 2011. Teori Portofolio dan Analisis Investasi. EdisiKedua. Bandung: Alfabeta.

24. Mahariana, I. D. G. P., \& Ramantha, I. W. (2014). Pengaruh kepemilikan manajerial dan kepemilikan institusional pada manajemen laba perusahaan manufaktur di bursa efek indonesia. E-Jurnal Akuntansi Universitas Udayana, 7(2), 519-528.

25. Mango, C., \& Dagron, G. (2016). Constantinople and its hinterland: papers from the Twenty-seventh Spring Symposium of Byzantine Studies, Oxford, April 1993. Routledge.

26. YUSRAN, I. A. R., Kristanti, F. T., \& Aminah, W. (2018). Pengaruh Indikator Good Corporate Governance terhadap Corporate Social Responsibility Disclosure. E-Proceeding of Management, 5(1).

27. Fricilia, F., \& Lukman, H. (2015). Analisis FaktorFaktor Yang Memengaruhi Praktik Manajemen Laba Pada Indsutri Perbankan Di Indonesia. Jurnal Akuntansi, 19(1), 79-92.

28. Wahono, B., \& Mardani, R. M. (2015). Pengaruh corporate governance dan kinerja keuangan terhadap manajemen laba pada perusahaan barang konsumsi yang terdaftar di bei periode 20082012. JEMA, 12(02).

29. Sugiyono, A., Anindita, M. S., \& Boedoyo, A. (2014). Indonesia energy outlook 2014. Agency for The Assesment and Application of Technology (BPPT).

30. Imam, P., \& Kpodar, K. (2016). Islamic banking: Good for growth?. Economic Modelling, 59, 387401.

31. Ghozali, I. (2011). Aplikasi analisis multivariate dengan program IBM.

32. Sutino, E. R. D., \& Khoiruddin, M. (2016). Pengaruh good corporate governance terhadap manajemen laba pada perusahaan yang masuk dalam JII (Jakarta Islamic Index) tahun 20122013. Management Analysis Journal, 5(3).

33. Nuryana, Y., \& Surjandari, D. A. (2019). The effect of good corporate governance mechanism, and earning management on company financial performance. Global Journal of Management and Business Research.

34. Normalita, I. S., \& Mahmud, A. (2017). Analysis of Capital Expenditure and Its Implications on 
Local Financial Independence. Accounting Analysis Journal, 6(2), 219-228.

35. Hanafi, A. H. (2016). Lembaga Pendidikan Tinggi Islam: Harapan, Tantangan, Paradigma, Dan Peranan Bahasa Arab. Al-Fikrah: Jurnal Manajemen Pendidikan, 1(1), 17-28.

36. Shah, S. Z. A. Safdar Ali Butt dan Arshad Hasan. 2009.“. Corporate Governance and Earnings Management an Empirical Evidence Form Pakistani Listed Companies". European Journal of Scientific Research.

37. Santoso, A., Puspitasari, D., \& Widyaswati, R.
(2016). Pengaruh Capital Intencity Ratio, Size, Earning Per Share Eps, Debt To Equity Ratio, Dividen Payout Ratio terhadap Manajemen Laba. Fokus Ekonomi: Jurnal Ilmiah Ekonomi, 11(1).

38. Santoso, A., Puspitasari, D., \& Widyaswati, R. (2016). Pengaruh Capital Intencity Ratio, Size, Earning Per Share Eps, Debt To Equity Ratio, Dividen Payout Ratio terhadap Manajemen Laba. Fokus Ekonomi: Jurnal Ilmiah Ekonomi, 11(1). 